\title{
Microbes influence the fractionation of arsenic in paddy soils with different fertilization regimes
}

\author{
Feng $\mathrm{Li}^{a, b}$, Yuan-Ming Zheng ${ }^{a}$, Ji-Zheng $\mathrm{He}^{a, *}$ \\ ${ }^{a}$ State Key Laboratory of Urban and Regional Ecology, Research Center for Eco-Environmental Sciences, Chinese Academy of Sciences, \\ Beijing, 100085, China \\ ${ }^{\mathrm{b}}$ Graduate University, Chinese Academy of Sciences, Beijing 100049, China
}

\section{A R T I C L E D A T A}

Article history:

Received 6 April 2008

Received in revised form

6 December 2008

Accepted 10 December 2008

Available online 19 January 2009

Keywords:

Arsenic

Fractionation

Microbes

Long-term fertilization

Paddy soil

Risk assessment

\begin{abstract}
A B S T R A C T
Sequential extraction procedures were used to investigate the influence of the microbes on the distribution of arsenic in a Chinese paddy soil under different long-term fertilization treatments. The paddy soil with four long-term fertilization treatments (CK, M, NPK and $\mathrm{NPK}+\mathrm{M})$ and three levels of arsenate addition $\left(0,50,100 \mathrm{mg} \mathrm{As} \mathrm{kg}^{-1}\right.$ dry soil), were selected to construct microcosms for laboratory incubation. After the incubation, soil samples were sequentially extracted to determine As in various fractions, i.e. water soluble (F0), exchangeable (F1), bound to carbonates (F2), bound to Fe and Mn oxides (F3), bound to organic matter and sulfides (F4), and residual (F5, mineral matrix). Results showed that most of the As was fixed by mineral matrix (F5, ratios ranging from $46.22 \%$ to $96.37 \%$ ), followed by As bound to $\mathrm{Fe}$ and $\mathrm{Mn}$ oxides (F3, ratios ranging from 3.14\% to $28.18 \%$ ), and the ratios of the other four fractions (F0, F1, F2 and F4) were mostly less than $10 \%$. The microbes in the paddy soil could make As transform from inactive fraction (F5) to relatively active fractions (F0, F1, F2 and F3) and thus increase its environmental risk. With the increase of the As addition levels and with the application of manure or chemical NPK fertilizers, As was distributed more in the relatively active fractions (FO, F1, F2, F3 and F4) in the paddy soil mediated by the microbes. In addition, Fe and Mn oxides could play an important role in decreasing the As leaching potential from the mineral matrix to soil solution and thus abate the As risk to human health.
\end{abstract}

(c) 2008 Elsevier B.V. All rights reserved.

\section{Introduction}

A wide range of arsenic (As) concentrations has been reported in soils around the world with an average of $5-10 \mathrm{mg} \mathrm{kg}^{-1}$ in uncontaminated soils (Fergusson, 1990). Arsenic may accumulate in agricultural soils due to the agricultural practices such as the applications of As-containing pesticides and herbicides, pig manure, and phosphorous fertilizers, and it has raised more concerns about the risk of As to the environment and human health (Gregory et al., 1996; Chirenje et al., 2003; Brouwere et al., 2004; Camm et al., 2004; Li and Chen, 2005). The accumulated As in agricultural soils can distribute among different soil components, such as organic matter, iron (Fe) and manganese (Mn) oxides, carbonates and sulfides, and such distribution could affect its mobility, bioavailability and toxicity (Cummings et al., 1999; Islam et al., 2004; deLemos et al., 2006). The distribution and redistribution process of As in soils can be influenced by microbial activities, because microbes could mediate the transformation of As and Asadsorbents (Bentley and Chasteen, 2002; Mukhopadhyay et al., 2002; Oremland and Stolz, 2003, 2005; Islam et al., 2004). It is reported that microbially mediated As release to the groundwater for drinking has threatened the health of millions of people in Bangladesh, West Bengal, and some regions of China (Smith et al., 2000; Shen et al., 2005).

\footnotetext{
* Corresponding author. Tel./fax: +861062849788.

E-mail address: jzhe@rcees.ac.cn (J.-Z. He).
} 
In order to properly understand the distribution of As in soils and its pathway to groundwater, plants and human, it is vitally important to be able to collect accurate and precise total and solid-phase partitioning data for As. Sequential extraction procedures are important techniques which reveal the distribution of elements including As in different fractions of soils and sediments (Chang and Jackson, 1957; Tessier et al., 1979; Wenzel et al., 2001). However, these procedures have been criticized because of their inherent disadvantages, such as lack of selectivity of the reagents used and the dependence of results on the procedure employed (Filgueiras et al., 2002; Nolan et al., 2003). Despite these disadvantages, sequential extraction procedures are widely used and remain an essential tool in determining fractionation of As in soils and other solid environmental samples (Keon et al., 2001; Van Herreweghe et al., 2003; Novoa-Munoz et al., 2007). Gleyzes et al. (2002) carried out careful comparisons of different extraction procedures and demonstrated that the classic one developed by Tessier et al. (1979) was more convenient than the anionic, P-based scheme of Chang and Jackson (1957) in evaluating the mobilization potential of As for their samples.

Paddy fields, which are mainly distributed in southern China, accounts for $25 \%$ of the total arable land in China. It has been reported that they may be contaminated through mining and smelting activities, with As accumulation in some places ( $\mathrm{Xu}$ and $\mathrm{Xu}, 1996)$. Though many studies have focused on As mobilization in sediments and soils (Carbonell-Barrachina et al., 1999; Turpeinen et al., 1999; Radloff et al., 2007), there is scant information about the effects of microbes on As partitioning in different fractions of paddy soils.

In this study, microcosms with different arsenate concentrations under four representative long-term fertilization regimes were constructed and incubated to simulate the arsenate polluted paddy soil environments. The aim of this work was to reveal how microbes could affect the distribution of natural or added As in fractions of the waterlogged paddy soil under different fertilization regimes.

\section{Materials and methods}

\subsection{Site description}

The long-term experimental station is established in 1978 by Chinese Academy of Sciences, located at Taoyuan county $\left(28^{\circ} 55^{\prime} \mathrm{N}, 111^{\circ} 26^{\prime} \mathrm{E}\right)$ of Hunan Province, central south China. The station has an annual precipitation of $1447.9 \mathrm{~mm} \mathrm{yr}^{-1}$ and an average annual temperature of $16.5^{\circ} \mathrm{C}$. The soil of the station was derived from Quaternary Red Clay.

The long-term fertilization experiment in the paddy field was initiated in 1990. The $\mathrm{pH}$ (water) and organic matter content of the surface soil (0-20 cm in depth) were 5.74 and $2.32 \%$, respectively, at the initiation of the experiment. In the long-term experiment, the fertilization treatments were $\mathrm{CK}$, $\mathrm{M}, \mathrm{NPK}$ and NPK $+\mathrm{M}$ (CK represents unfertilized treatment; N, $\mathrm{P}$ and $\mathrm{K}$ represent chemical nitrogen, phosphorus and potassium fertilizers, respectively; $M$ represents manure) with three replicates for each treatment. The cropping system of the paddy field was early rice-late rice-green manure (the green manure was only planted in the treatments with manure). The chemical fertilizers applied were urea (182.3 $\mathrm{kg} \mathrm{N} \mathrm{hm}^{-2} \mathrm{yr}^{-1}$ ), super phosphate $\left(39.3 \mathrm{~kg} \mathrm{P} \mathrm{hm}^{-2}\right.$ $\mathrm{yr}^{-1}$ ) and potassium chloride (137.0 $\mathrm{kg} \mathrm{K} \mathrm{hm}^{-2} \mathrm{yr}^{-1}$ ). The $40 \%$ of the recommended $\mathrm{N}$ with full $\mathrm{P}$ were applied for early rice in April, and the remaining $\mathrm{N}$ with full $\mathrm{K}$ were applied for late rice in July.

Surface soil (0-20 cm in depth) samples were collected from one replicate of the four fertilization treatments in January 2006. One part of the fresh soil was thoroughly mixed and passed through a $2 \mathrm{~mm}$ sieve and stored at $-20{ }^{\circ} \mathrm{C}$, while the remaining soil was air-dried, mildly ground and passed through a $2 \mathrm{~mm}$ and a $0.149 \mathrm{~mm}$ sieve and stored at room temperature. The soil characteristics are shown in Table 1.

\subsection{Heterotrophic microbial counting experiment}

Total heterotrophic microbial count (CFU) and As(V)-resistant microbial count (CFUAS) were determined on a beef extractpeptone medium (beef extract, 3.0 g; peptone, 10.0 g; sodium chloride, 5.0 g; agar, 15.0 g; water, 1000 ml) (Fan et al., 1992). Addition levels of sodium arsenate in the plates for CFU count (the plate was called "T-plate") and CFUAS (the plate was

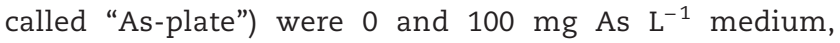
respectively. The arsenate addition level was selected for the As concentrations in the medium accounting for 3-4 times higher than the contamination threshold of the China Environmental Quality Standard for Soils $\left(\leq 30 \mathrm{mg} \mathrm{kg}^{-1}\right.$, $\mathrm{pH}<6.0$, paddy field). Each fresh soil sample of $1.0 \mathrm{~g}(2 \mathrm{~mm}$ in size, stored at $-20{ }^{\circ} \mathrm{C}$ ) was diluted to $10^{-4} \mathrm{~g}$ soil $\mathrm{L}^{-1}$ (for " $\mathrm{T}$ plate") and $10^{-3}$ g soil L $\mathrm{L}^{-1}$ (for "As-plate") with sterilized water. Then $0.2 \mathrm{ml}$ of the each suspension was smeared on the "Tplate" and the "As-plate" with three replications, respectively. The plates were incubated aerobically for 10 days at room temperature in darkness, and those plates containing 30 to 300 microbial colonies were enumerated.

\subsection{Microcosm experiment}

Two groups of incubation were conducted in this experiment. One was the "natural group" with living microbes in the soil samples during the incubation, and the other was the "control

\begin{tabular}{|c|c|c|c|c|c|}
\hline Fertilization $^{a}$ & $\begin{array}{c}\mathrm{pH} \\
\text { (water) }\end{array}$ & $\begin{array}{c}\mathrm{OM} \\
\left(\mathrm{g} \mathrm{kg}^{-1}\right)\end{array}$ & $\begin{array}{c}\text { Clay } \\
\text { content } \\
(\%)\end{array}$ & $\begin{array}{l}\text { Total As } \\
\left(\mathrm{mg} \mathrm{kg}^{-1}\right)\end{array}$ & $\begin{array}{c}\text { Total } \\
\mathrm{Fe} \\
\left(\mathrm{Fe}_{2} \mathrm{O}_{3},\right. \\
\left.\mathrm{g} \mathrm{kg}^{-1}\right)\end{array}$ \\
\hline $\mathrm{CK}$ & 4.81 & 27.4 & 30.5 & 11.83 & 34.1 \\
\hline $\mathrm{M}$ & 4.66 & 36.5 & 33.2 & 11.41 & 30.8 \\
\hline NPK & 4.69 & 28.4 & 33.9 & 12.41 & 32.7 \\
\hline $\mathrm{NPK}+\mathrm{M}$ & 4.62 & 38.7 & 35.8 & 10.31 & 27.8 \\
\hline
\end{tabular}

${ }^{\mathrm{a}} \mathrm{CK}$ represents unfertilized (control) treatment; $\mathrm{N}, \mathrm{P}$ and $\mathrm{K}$ represent chemical nitrogen, phosphorus and potassium fertilizers, respectively; $\mathrm{M}$ represents manure. 
group" where the soil samples were autoclaved at $125^{\circ} \mathrm{C}$ for $2 \mathrm{~h}$ before incubation and formaldehyde (0.04\%) was added to "kill" any possible living microbes during the incubation. The advantage of formaldehyde for inhibiting the microbial activities is that it does not cause any changes in dissolved nutrient concentrations or $\mathrm{pH}$ in soil (Tuominen et al., 1994; Kairesalo et al., 1995).

Fresh soil samples (equivalent to $10.0 \mathrm{~g}$ of dry soil) were mixed with deionized water to meet the total weight of $20.0 \mathrm{~g}$ (water: dry soil=1:1 in w/w) in $250 \mathrm{ml}$ centrifuge tubes to keep the soil samples submerged as they were in the paddy field, and the mixtures were equilibrated for 7 days at room temperature. After equilibration, sodium arsenate was added to the tubes at levels of 0,50 and $100 \mathrm{mg} \mathrm{As} \mathrm{kg}^{-1}$ dry soil and was thoroughly mixed with the soil. The under-part of the centrifuge tubes was enveloped by aluminum foil to keep the samples in darkness. The centrifuge tubes were left open and incubated at room temperature for 30 days to simulate the paddy soil environment. The weights of the tubes were recorded at the beginning and deionized water was supplemented every two days to keep the initial weight. After incubation, the soil was sequentially extracted following the method described below.

\subsection{Sequential extraction procedure}

Sequential extraction of As was performed using the procedure reported by Tessier et al. (1979) with a few modifications (Carbonell-Barrachina et al., 1999) as described below.

(1) Water soluble fraction (F0): Soil samples were taken after 30 days incubation and $70 \mathrm{ml}$ of water was added to make the soil:water ratio reached 1:8. Then the soil was thoroughly mixed with water.

(2) Exchangeable fraction (F1): The solid phase from F0 was extracted at room temperature for $30 \mathrm{~min}$ with $80 \mathrm{ml}$ of magnesium chloride solution (1.0 $\mathrm{M} \mathrm{MgCl}_{2}, \mathrm{pH} 7.0$ ) with continuous agitation.

(3) Bound to carbonate fraction (F2): The residue from F1 was extracted at room temperature for $5 \mathrm{~h}$ with $80 \mathrm{ml}$ of sodium acetate solution (1.0 M NaOAc, adjusted to $\mathrm{pH}$ 5.0 with acetic acid). These samples were also agitated continuously.

(4) Bound to Fe and Mn oxides fraction (F3): The residue from F2 was extracted at $96{ }^{\circ} \mathrm{C}$ for $6 \mathrm{~h}$ with $200 \mathrm{ml}$ of $0.08 \mathrm{M} \mathrm{NH}_{2} \mathrm{OH} \cdot \mathrm{HCl}$ in $250 \mathrm{ml} \mathrm{L} \mathrm{L}^{-1}$ acetic acid. These samples were occasionally agitated.

(5) Bound to organic matter and sulfides fraction (F4): The residue from $\mathrm{F} 3$ was extracted at $85^{\circ} \mathrm{C}$ for $2 \mathrm{~h}$ with $30 \mathrm{ml}$ of $0.02 \mathrm{M} \mathrm{HNO}_{3}$, then $50 \mathrm{ml} 300 \mathrm{ml} \mathrm{L}^{-1} \mathrm{H}_{2} \mathrm{O}_{2}$ (adjusted to pH 2.0 with $\mathrm{HNO}_{3}$ ) was added, and the extraction continued at $85^{\circ} \mathrm{C}$ for another $3 \mathrm{~h}$. After cooling, $50 \mathrm{ml}$ of $3.2 \mathrm{M} \mathrm{NH}_{4} \mathrm{OAc}$ in $20 \mathrm{ml} \mathrm{L}^{-1} \mathrm{HNO}_{3}$ was added and the sample was diluted to $200 \mathrm{ml}$ with deionized water. The samples were agitated continuously for $30 \mathrm{~min}$. $\mathrm{NH}_{4} \mathrm{OAc}$ was added to prevent the adsorption of extracted metals onto the oxidized soil.

(6) Residual fraction (F5, mineral matrix): The residue from F4 was digested with an $\mathrm{HCl}-\mathrm{HNO}_{3}-\mathrm{HClO}_{4}$ mixture according to the procedure described below for total As analysis.

The above sequential extractions were conducted in $250 \mathrm{ml}$ centrifuge tubes which prevented any loss of soil between the successive extractions. Separation was conducted by centrifuge at $5000 \mathrm{rpm}$ for $30 \mathrm{~min}$. The supernatant was filtered through a $0.45 \mu \mathrm{m}$ filter and then analyzed for As. The residue was rinsed with $80 \mathrm{ml}$ deionized water and centrifuged at $5000 \mathrm{rpm}$ for $30 \mathrm{~min}$. This second supernatant was discarded.

\subsection{Analytical methods}

Soil samples were characterized for $\mathrm{pH}$ (water), clay content, and organic matter content using standard protocols (Lu, 2000). For analysis of the total As, residual As (F5) and total Fe, soil samples were digested in digestion tubes with $\mathrm{HCl}-\mathrm{HNO}_{3}-\mathrm{HClO}_{4}$ taking $0.15 \mathrm{~g}$ of each sample. The soil sample was firstly digested with a $5.0 \mathrm{ml}$ of aqua regia $\left(\mathrm{HCl}: \mathrm{HNO}_{3}=3: 1 \mathrm{in} \mathrm{v} / \mathrm{v}\right.$ ) at $120^{\circ} \mathrm{C}$ for about $12 \mathrm{~h}$. Then $4.0 \mathrm{ml}$ of $\mathrm{HClO}_{4}$ was added and the soil sample was digested at $120^{\circ} \mathrm{C}$ continuously until it became white or gray-white. The digested solution was transferred to a volumetric flask and diluted to $50.0 \mathrm{ml}$ with deionized water.

As concentrations in digested solutions (total As and F5) and the chemical extracts (F0, F1, F2, F3 and F4) were determined using hydride generation atomic fluorescence spectrometry (AFS2202E, Haiguang Company, Beijing, China). Quality assurance was conducted by spiking the solutions and the extracts with certified element standards. The recovery of the sequential extraction procedure was estimated comparing the sum of the six fractions with a single digestion of total As. Total Fe concentrations in digested solutions were determined by ICPOES (Optima 2000 DV, PerkinElmer Co., USA).

In this study, deionized water used in preparing stock solutions was obtained from a Milli-Q system (Milli-Q synthesis A10, Millipore Corp., Bedford, MA, USA). All glassware was previously soaked in $15 \% \mathrm{HNO}_{3}(\mathrm{v} / \mathrm{v})$ and rinsed with deionized water. All reagents were of reagent grade.

\subsection{Statistical analysis}

The experimental data were statistically analyzed. The test of significance of different parameters was calculated according to Duncan Multiple Range Test (DMRT, ANOVA) or T-Test for Dependent Samples at 5\% level in STATISTICA (Version 6.0, Statsoft Inc.).

\section{Results}

\subsection{Heterotrophic microbial counts (CFU) and As(V)-} resistant microbial counts (CFUAS) of the paddy soil

CFUs were significantly higher than CFUASs $(P<0.05$, Fig. 1$)$ in the four treatments, indicating that the heterotrophic microbial colonies were strongly inhibited by the added As(V) under the current level $\left(100 \mathrm{mg} \mathrm{kg}^{-1}\right)$.

The highest CFU (4.64E $+06 \mathrm{cfu} \mathrm{g}^{-1}$ dry soil) and CFUAS $\left(1.09 \mathrm{E}+05 \mathrm{cfu} \mathrm{g}^{-1}\right.$ dry soil) were found in the $\mathrm{M}$ and $\mathrm{NPK}+\mathrm{M}$ 


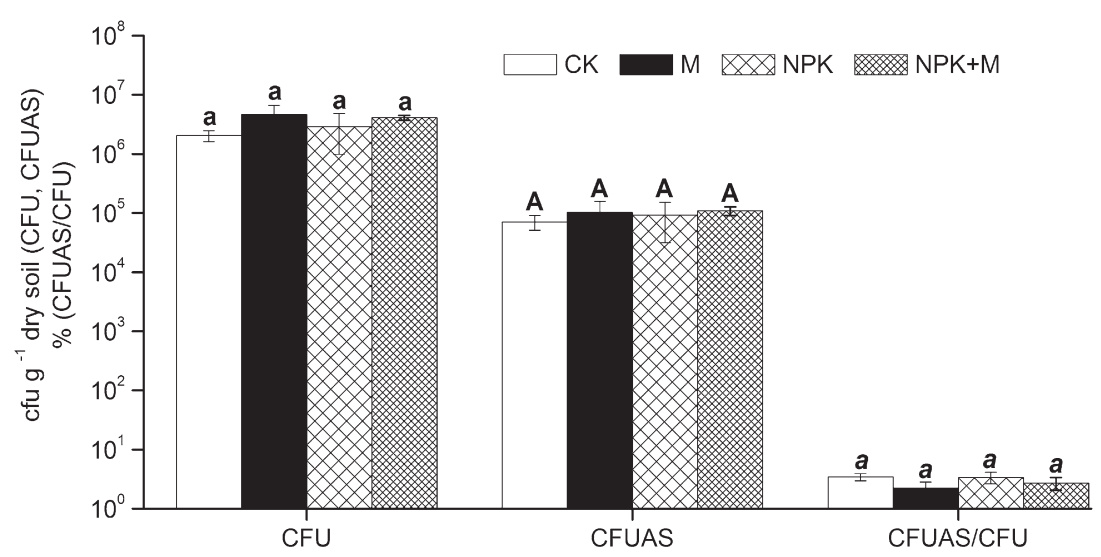

Fig. 1 - Total heterotrophic microbial counts (CFU), As(V)-resistant microbial counts (CFUAS), and ratio of CFUAS to CFU (CFUAS/ CFU) of a paddy soil under different fertilization regimes. Different letters within the columns of CFU, CFUAS or CFUAS/CFU (small letters on columns of CFU, capital letters on columns of CFUAS, small italic letters on columns of CFUAS/CFU) indicate significant differences among the treatments $(P<0.05)$.

treatments, respectively, while the lowest CFU $(2.04 \mathrm{E}+06 \mathrm{cfu}$ $\mathrm{g}^{-1}$ dry soil) and CFUAS (7.07E $+04 \mathrm{cfu} \mathrm{g}^{-1}$ dry soil) were all found in the CK treatment. The ratios of CFUAS to CFU (CFUAS/CFU) were all lower than 5\%, ranging from $2.23 \%(\mathrm{M})$ to $3.44 \%$ (CK). There were no significant differences among the fertilization treatments in CFUs, CFUASs and CFUAS/CFU (Fig. 1), indicating that fertilization had minor influences on the soil total heterotrophic microbes, As(V)-resistant microbes and the ratios of $\mathrm{As}(\mathrm{V})$-resistant microbes to soil total microbes, respectively.

This experiment reveals that the $\mathrm{As}(\mathrm{V})$-resistant microbes still exist even in the paddy soil with low As concentrations, though the ratios of them is very low $(<5 \%)$, and the low ratios of the As(V)-resistant microbes may be correlated with the low soil As concentrations (Table 1).

\subsection{As fractionation in microcosms}

The As recoveries of sequential extraction procedure ranged from $84.31 \%$ to $102.99 \%$ (Table 2), showing a satisfactory quality control (Van Herreweghe et al., 2003).

\subsubsection{As partition among the fractions}

In the paddy soil without arsenate addition, the dominant As fraction was residual (F5, 90.15-96.37\%), followed by As bound to Fe and Mn oxides (F3, 3.14-5.30\%). The ratios of the other four fractions were mostly less than $1.0 \%$ and the order in the control group was F0 (0.11-0.30\%)> F4 (0-0.49\%)> F2 (0-0.18\%)> F1 (0.05$0.08 \%)$, while in the natural group the order was F2 (0.50-1.79\%)> F0 (0.57-1.49\%)> F1 (0.18-0.84\%)> F4 (0-0.43\%) (Figs. 2 and 3).

In the paddy soil with 50 and $100 \mathrm{mg} \mathrm{kg}^{-1}$ arsenate additions, the dominant As fraction was residual (F5, 46.22-84.94\%), followed by As bound to Fe and Mn oxides (F3, 9.13-28.18\%), As bound to carbonates (F2, 3.17-9.73\%), water soluble As (F0, 1.46$10.23 \%$ ), exchangeable As (F1, 0.95-5.03\%), and As bound to organic matter and sulfides (F4, 0.18-1.65\%) (Figs. 2 and 3).

\subsubsection{As partition mediated by microbes}

In the paddy soil without arsenate addition, the As ratios of F0, F1 and F2 in the natural group were significantly higher than those in the control group, while opposite for F5 (T-Test for Dependent Samples, $P<0.05$, Fig. 2). Comparing with the fractions in the control group, the decreases of F5 in the natural group were all lower than $10 \%$, ranging from $0.51 \%$ to $5.65 \%$, and the increases of the other fractions, i.e. F0, F1 and F2, were similar to each other ranging from $0.13 \%$ to $1.61 \%$ (Fig. 3). These results indicated that the microbial activities in the paddy soil without the arsenate addition led to the release of soil As from the mineral matrix (F5) and the released As was mainly redistributed to those bound to carbonate (F2), water soluble (F0) and exchangeable (F1) fractions.

In the paddy soil with $50 \mathrm{mg} \mathrm{kg}^{-1}$ and $100 \mathrm{mg} \mathrm{kg}^{-1}$ arsenate additions, the As ratios of F0, F1, F2 and F3 in the natural group were significantly higher than those in the control group, while the ratios of F4 and F5 between the control group and the natural group were opposite ( $T$-Test for Dependent Samples, $P<0.05$, Fig. 2). Comparing with the fractions in the control group, the decreases of F5 in the natural group all exceeded 10\%, ranging from $12.35 \%$ to $23.88 \%$, and the decreases of $\mathrm{F} 4$ fraction were all lower than $1 \%$ ranging from $0.16 \%$ to $0.89 \%$; meanwhile, the increases of $\mathrm{F} 3$ fraction were the highest one ranging from $10.65 \%$ to $17.85 \%$, and the increases of the other fractions, i.e. F0, F1 and F2, were similar to each other ranging from $0.15 \%$ to $5.70 \%$ (Fig. 3). These results indicated that the microbial activities in the paddy soil with the arsenate addition led to the release of soil As from the mineral matrix (F5) and organic matter (F4), and the released As was mainly redistributed to those bound to Fe and $\mathrm{Mn}$ oxides fraction (F3), and less to those water soluble (F0), exchangeable (F1) and bound to carbonate (F2) fractions.

\subsubsection{As partition under different fertilization regimes} In the control and the natural groups of the paddy soil with different arsenate additions, the As ratios of F0, F1, F2, F4 and F3 (only in the paddy soils with $50 \mathrm{mg} \mathrm{kg}^{-1}$ and $100 \mathrm{mg} \mathrm{kg}^{-1}$ arsenate additions) of the CK treatment were the lowest one and it was significantly lower than the highest one $(\mathrm{NPK}+\mathrm{M})$ in the control and the natural groups, while as to the ratio of F5, the CK treatment was the highest one and it was significantly higher than the lowest one $(\mathrm{NPK}+\mathrm{M})$ in the control and the natural groups $(P<0.05$, Fig. 3). 
Table 2 - As recoveries of sequential extraction procedure in a paddy soil under different arsenate addition levels

Fertilization $^{\mathrm{a}} \quad$ Sum of As Total As As fractions $\left(\mathrm{mg} \mathrm{kg}^{-1}\right) \quad\left(\mathrm{mg} \mathrm{kg}^{-1}\right) \quad$ recovery

(\%)

Paddy soil with $0 \mathrm{mg} \mathrm{kg}^{-1}$ arsenate addition

\begin{tabular}{lrrr}
\hline CK (CG) & $12.18 \pm 0.54$ & 11.83 & $102.99 \pm 4.61$ \\
M (CG) & $10.27 \pm 0.17$ & 11.41 & $90.04 \pm 1.52$ \\
NPK (CG) & $10.89 \pm 0.27$ & 12.41 & $89.74 \pm 2.22$ \\
NPK +M (CG) & $9.06 \pm 0.17$ & 10.31 & $87.86 \pm 1.65$ \\
CK (NG) & $11.43 \pm 0.27$ & 11.83 & $96.65 \pm 2.31$ \\
M (NG) & $9.67 \pm 0.06$ & 11.41 & $84.72 \pm 0.57$ \\
NPK (NG) & $10.23 \pm 0.19$ & 12.41 & $84.31 \pm 1.57$ \\
NPK+M (NG) & $8.90 \pm 0.26$ & 10.31 & $86.28 \pm 2.53$
\end{tabular}

Paddy soil with $50 \mathrm{mg} \mathrm{kg}^{-1}$ arsenate addition

\begin{tabular}{llll}
\hline CK (CG) & $60.45 \pm 2.73$ & 61.83 & $97.77 \pm 4.42$ \\
M (CG) & $59.60 \pm 0.11$ & 61.41 & $97.05 \pm 0.18$ \\
NPK (CG) & $60.64 \pm 0.40$ & 62.41 & $97.58 \pm 0.64$ \\
NPK +M (CG) & $56.51 \pm 3.00$ & 60.31 & $93.70 \pm 4.98$ \\
CK (NG) & $59.93 \pm 0.63$ & 61.83 & $96.93 \pm 1.03$ \\
M (NG) & $57.89 \pm 1.92$ & 61.41 & $94.27 \pm 3.13$ \\
NPK (NG) & $59.12 \pm 1.17$ & 62.41 & $95.14 \pm 1.89$ \\
NPK+M (NG) & $54.82 \pm 1.13$ & 60.31 & $90.89 \pm 1.87$
\end{tabular}

Paddy soil with $100 \mathrm{mg} \mathrm{kg}^{-1}$ arsenate addition

\begin{tabular}{llll}
\hline CK (CG) & $108.87 \pm 1.05$ & 111.83 & $97.35 \pm 0.94$ \\
M (CG) & $106.41 \pm 1.74$ & 111.41 & $95.51 \pm 1.57$ \\
NPK (CG) & $107.77 \pm 2.67$ & 112.41 & $96.11 \pm 2.38$ \\
NPK +M (CG) & $106.38 \pm 2.01$ & 110.31 & $96.44 \pm 1.82$ \\
CK (NG) & $108.35 \pm 3.09$ & 111.83 & $96.89 \pm 2.77$ \\
M (NG) & $105.05 \pm 1.12$ & 111.41 & $94.29 \pm 1.01$ \\
NPK (NG) & $107.00 \pm 1.19$ & 112.41 & $95.42 \pm 1.06$ \\
NPK+M (NG) & $101.71 \pm 0.41$ & 110.31 & $92.20 \pm 0.37$
\end{tabular}

${ }^{\mathrm{a}} \mathrm{CK}$ represents unfertilized (control) treatment; N, P and $\mathrm{K}$ represent chemical nitrogen, phosphorus and potassium fertilizers, respectively; M represents manure; CG: Control Group, which represents the paddy soil without living microbes during the incubation; NG: Natural Group, which represents the paddy soil with living microbes during the incubation.

In the control and the natural groups, the As ratios of F0, F1, F2, F4 and F3 (except for the control group of the paddy soils without the arsenate addition) in the treatments with manure application $(\mathrm{M}, \mathrm{NPK}+\mathrm{M})$ were significantly higher than those in the treatments without manure application (CK, NPK), while the ratio of F5 was opposite ( $T$-Test for Dependent Samples, $P<0.05$, Fig. 3). With the application of manure, the increases of F0, F2 and F3 were similar to each other ranging from $0.13 \%$ to $7.03 \%$ and were significantly higher than those of F1 and F4 (0.05-1.51\%) (T-Test for Dependent Samples, $\mathrm{P}<0.05$, Fig. 3). This indicated that the residual As fraction (F5) of the paddy soil decreased due to the application of manure, and the released As was mainly redistributed to those water soluble (F0), bound to carbonate (F2) and bound to Fe and Mn oxides (F3) fractions, and less redistributed to those exchangeable (F1) and bound to organic matter and sulfides fractions (F4).

In the natural group, the As ratios of F0, F1, F2, F4 and F3 (only in the paddy soil without the arsenate addition) in the treatments with chemical NPK fertilizers application (NPK, $\mathrm{NPK}+\mathrm{M}$ ) were significantly higher than those in the treatments without chemical NPK fertilizers application (CK, M) (T-Test for Dependent Samples, $P<0.05$ ), while the ratio of F5 was opposite $(P<0.05$, Fig. 3). With the application of chemical NPK fertilizers, the increases of F0, F2 and F3 were similar to each other ranging from $0.25 \%$ to $6.05 \%$ and were significantly higher than those of F1 and F4 (0.11-1.69\%) (T-Test for Dependent Samples, $P<0.05)$. This indicated that due to the application of chemical NPK fertilizers, the released As from the mineral matrix (F5) was mainly redistributed to those water soluble (F0) and bound to carbonate fractions (F2), and less redistributed to those exchangeable (F1) and bound to organic matter and sulfides fractions (F4).

\subsubsection{As partition under different As addition levels}

In the control and the natural groups, the As ratios of F0, F1, F2, F3 and F4 in the paddy soil with $0 \mathrm{mg} \mathrm{kg}^{-1}$ and $50 \mathrm{mg} \mathrm{kg}^{-1}$ arsenate additions were significantly lower than those with $50 \mathrm{mg} \mathrm{kg}^{-1}$ and $100 \mathrm{mg} \mathrm{kg}^{-1}$ arsenate additions, respectively, while the ratio of $\mathrm{F} 5$ was opposite between the different arsenate addition soil samples (T-Test for Dependent Samples, $P<0.05$, Fig. 3). With the increase of the As addition levels, the increases of F3 (0.70-22.83\%) were significantly higher than the other fractions (T-Test for Dependent Samples, $P<0.05)$, i.e. F2 (0.60-7.94\%), F0 (0.27-8.47\%), F1 (0.03-3.97\%) and $F 4(0.06-0.95 \%)$. This indicated that residual As fraction (F5) of the paddy soil decreased with the increase of the As addition levels, and the released As from the F5 was mainly redistributed to those bound to Fe and Mn oxides fraction (F3), and less redistributed to those bound to carbonate (F2), water soluble (F0), exchangeable (F1) and bound to organic matter and sulfides (F4) fractions.

\section{Discussion}

In the microcosms experiment, the six As fractions separated by the Tessier procedure can be divided into two fractions according to their mobility and bioaccessibility. One was the inactive fraction $\mathrm{F} 5$ which was relatively stable and inactive in soil and thus relatively safe to the environment. The other was the relatively active fraction, including the bioavailable water soluble As (FO) and the As bound to soil particles and chemical compounds (F1, F2, F3 and F4), which may release bioavailable As anion to soil solution from the adsorbents when soil condition changed (Tadanier et al., 2005), and the released As anion may accumulate in crops or groundwater and thus bring risk to human health by food-chain or drinking water.

\subsection{Effect of soil characteristics on the As partition among the soil fractions}

As partition in the paddy soil was closely correlated with the soil characteristics. The selected paddy soil was derived from Quaternary Red Clay with high clay and Fe contents (mainly be composed of Fe oxides which have strong ability to adsorb As), low carbonate content and low pH (Table 1), 

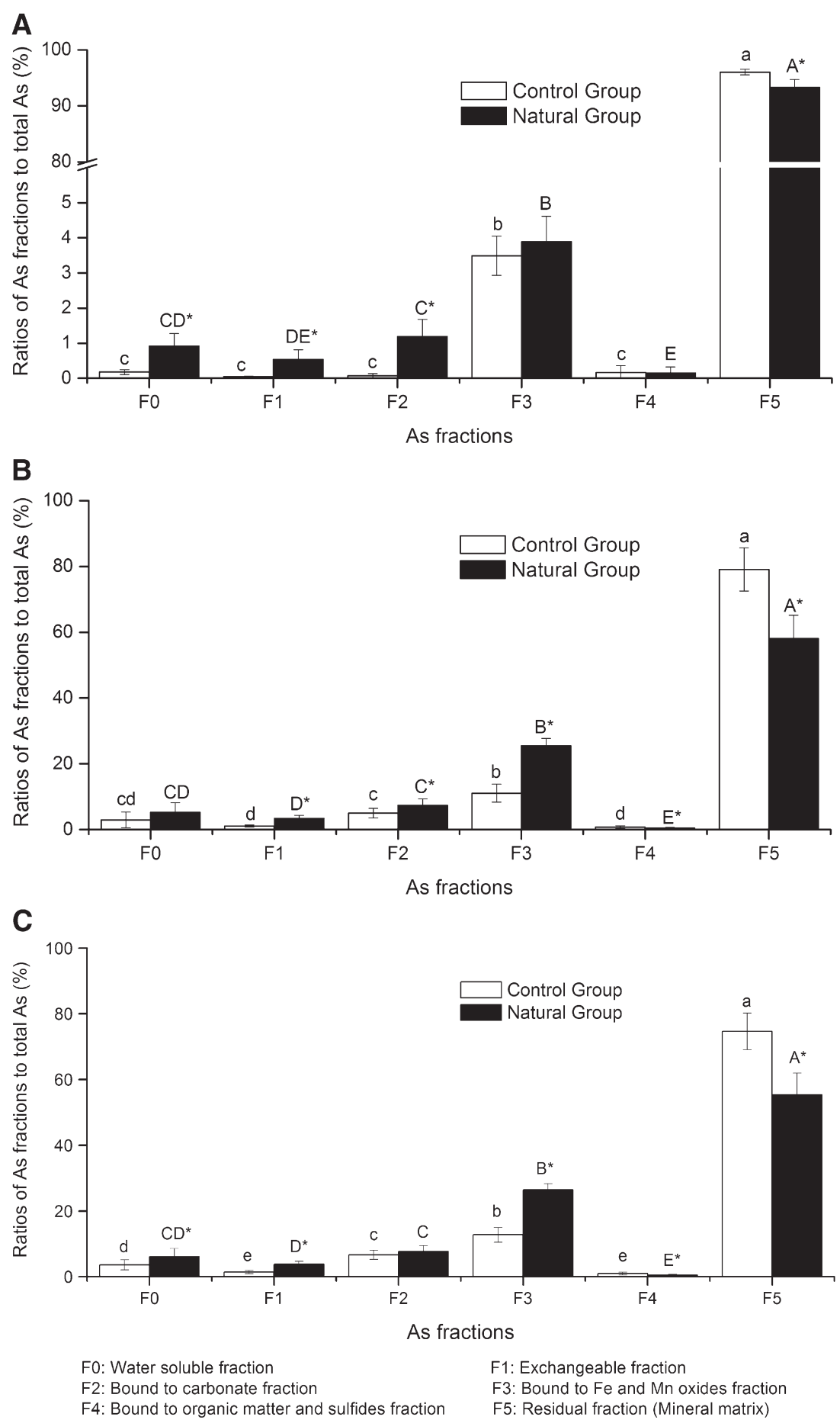

Fig. 2-Average ratios of each As fraction in the paddy soils with $0 \mathrm{mg} \mathrm{kg}^{-1}$ arsenate addition (A), $50 \mathrm{mg} \mathrm{kg}^{-1} \mathrm{arsenate}$ addition (B) and $100 \mathrm{mg} \mathrm{kg}^{-1}$ arsenate addition (C). Different letters within the columns of Control Group or Natural Group (small letters on columns of Control Group, capital letters on columns of Natural Group) indicate significant differences among the fractions $(P<0.05)$. Asterisks $(*)$ above the columns of Natural Group indicate significant differences between Natural Group and Control Group in each fraction $(P<0.05)$. Control Group represents the paddy soils without living microbes during the incubation, and Natural Group represents the paddy soils with living microbes during the incubation.

and this may explain the high ratio of residual fraction (F5), the high ratio of that bound to $\mathrm{Fe}$ and $\mathrm{Mn}$ oxides fraction (F3) and the low ratio of As bound to carbonate (F2). Clay content has been reported to be a soil property which is frequently correlated with As retention in soils (Adriano, 2001). It was reported that the most important As fractions 

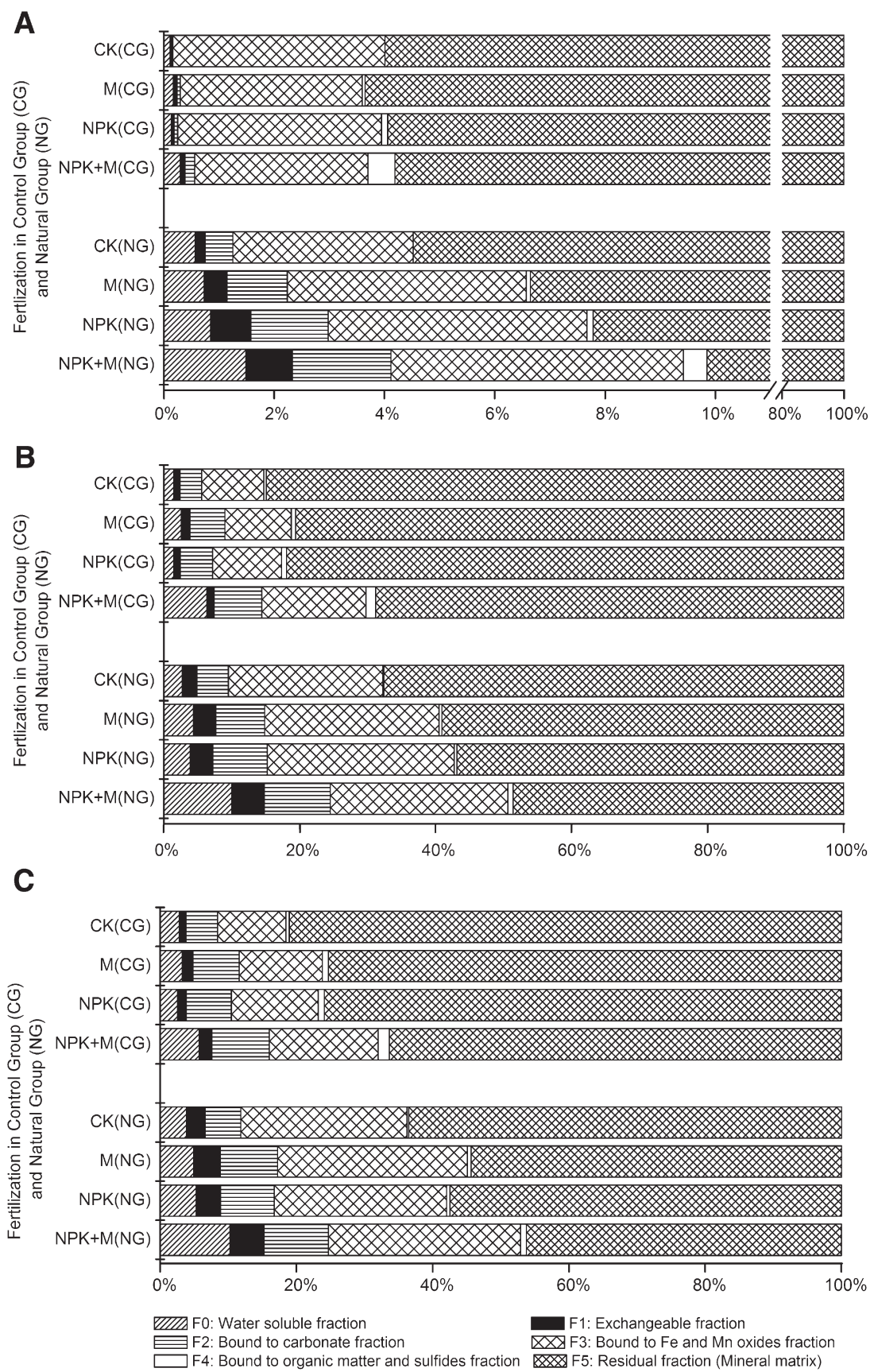

Fig. 3- Partitioning of As among the fractions in a paddy soil under different fertilization regimes with $0 \mathrm{mg} \mathrm{kg}^{-1}$ arsenate addition (A), $50 \mathrm{mg} \mathrm{kg}^{-1}$ arsenate addition (B) and $100 \mathrm{mg} \mathrm{kg}^{-1}$ arsenate addition (C). Control Group represents the paddy soil without living microbes during the incubation, and Natural Group represents the paddy soil with living microbes during the incubation.

were the residual As (F5) and As bound to Fe and Mn oxides (F3) in the As contaminated soils (Voigt et al., 1996; Roussel et al., 2000; Cances et al., 2005; Okonkwo, 2007).

The As bound to organic matter and sulfides (F4) has the lowest ratio among the fractions, though the organic matter contents were high in the paddy soil (Table 1). Apparently, soil organic matter did not act as a major scavenger of As in the paddy soil in the presence of stronger As retainers. Sarkar et al. (2007) also found that the organic-bound As fraction was negligible in the As polluted soils. Arsenic has been reported to have strong affinity for sulfur (S) (Masscheleyn et al., 1991), but the result in this case does not reveal the affinity, and this may be correlated with the low sulfide concentration of the paddy soil. It has been reported that As sulfides are unusual to be found in soils even though they would be the stable solid fraction under reducing conditions such as would be found in waterlogged soils (O’Neill, 1995).

\subsection{Effect of microbes on soil As fractionation}

Microbes have strong impacts on the As release from inactive fraction (F5) to relatively active fractions (F3, F0, F1 and F2), 
and the Fe and Mn oxides act as an important role in reducing the leaching potential of As to soil solution and thus abate the risk of As-contamination from exposure to groundwater, typically used as drinking water in many paddy regions of China. In the anaerobic soil, arsenate can be reduced to arsenite by microbes and decrease its affinity to soil particles including the mineral matrix (Mukhopadhyay et al., 2002; Oremland and Stolz, 2003; Islam et al., 2004), and this may explain the decrease of F5. While, the decrease of F4 may be correlated with the microbially mediated consumption of the As-adsorbing organic matter. It has been reported that the increases of those bound to carbonate As fraction (F2) and water soluble As fraction (FO) coupled with increasing microbial activities (Bachofen et al., 1995; Ahmann et al., 1997; Guo et al., 1997; Turpeinen et al., 1999).

In addition, the microbial reduction of As-adsorbing crystalline Fe(III) oxides to soluble Fe(II) can lead to the release of As to soil solution in the anaerobic soil, and this is widely thought to be responsible for the genesis of As-rich reducing ground waters found in many parts of the world, most notably in Bangladesh and West Bengal, India (Anawar et al., 2006; Coker et al., 2006). While in this case, the microbial activities lead to the increase of As bound to Fe and Mn oxides (F3) in the anaerobic paddy soil. This may be due to the oxidation of soluble Fe(II) in oxygen-rich upper water and the subsequent precipitation of Fe(III) oxyhydroxides to restore the ability to adsorb As, and the formation of the visible iron films on the interface of water and soil may provide evidence for the supposition.

\subsection{Effect of fertilization on soil As fractionation}

The application of manure or chemical NPK fertilizers in the natural group can lead to the As release from inactive fraction (F5) to relatively active fractions (F0, F2 and F3), and the Fe and Mn oxides can reduce the As leaching potential to soil solution. This may be explained by that the microbial activities which lead to the redistribution of As among the fractions were stimulated by the applied manure or chemical NPK fertilizers which provided nutrient sources, such as carbon or nitrogen sources (Brouwere et al., 2004; Signes-Pastor et al., 2007), and the result that the lowest CFUs and CFUASs were all found in the CK treatment may provide evidence for the supposition. It was reported that the As solubility was correlated with organic carbon in soils and sediments (Harvey et al., 2002; Jackson et al., 2006; Rowland et al., 2006), and the leaching of As to soil solution was enhanced by the added carbon sources (Turpeinen et al., 1999). Meanwhile, the $P$ in the applied manure or chemical fertilizers may compete with As for binding sites in the soil matrix and this may also be a reason of the increased As mobility (Brouwere et al., 2004; Signes-Pastor et al., 2007).

In the four long-term fertilization treatments, the As risk to environment in the NPK $+\mathrm{M}$ treatment was higher than the other treatments (CK, M, NPK) if the paddy soil was polluted by arsenate under the similar conditions of this experiment and the NPK + M treatment should be paid more attention to. If the paddy soil was polluted by arsenate, it is recommended that the NPK + M treatment should be replaced by NPK treatment to reduce its environmental risk and maintain its productivity at the same time.

\subsection{Effect of arsenate addition levels on soil As fractionation}

With the increase of the soil As concentrations, the As retention ability of soil mineral matrix was saturated at the present arsenate addition levels $\left(50 \mathrm{mg} \mathrm{kg}^{-1}\right.$ and $100 \mathrm{mg} \mathrm{kg}^{-1}$ ), and the Fe and Mn oxides act as an important role in reducing the As leaching from mineral matrix to soil solution.

Water soluble (F0) and exchangeable As fractions (F1) have been reported to be positively correlated with bioaccessible As and may bring more risk to human health than the other fractions (Sarkar et al., 2007). In the paddy soil without arsenate addition, ratios of these two fractions were very low $(<2 \%)$ and the risk to environment was minimal considering the low As concentrations of the soil ( $\left.<15 \mathrm{mg} \mathrm{kg}^{-1}\right)$. While in the paddy soils with the arsenate addition, the concentrations of water soluble As (FO) all exceeded the safe limit for drinking water $\left(10 \mu \mathrm{g} \mathrm{L}^{-1}\right)$ as recommended by the World Health Organization (WHO), and the concentrations of exchangeable As (F1) were all higher than the contamination threshold of the China Environmental Quality Standard for Soils ( $\leq 30 \mathrm{mg} \mathrm{kg}^{-1}, \mathrm{pH}<6.0$, paddy field). This indicated that if the paddy soil was polluted by arsenate at the current addition levels, the soil bioaccessible As concentrations may be very high and it may bring risk to human health by contaminating the drinking groundwater or accumulating in rice grain for food.

\section{Conclusions}

In the incubated paddy soils with different arsenate addition levels $\left(0 \mathrm{mg} \mathrm{kg}^{-1}, 50 \mathrm{mg} \mathrm{kg}^{-1}\right.$ and $\left.100 \mathrm{mg} \mathrm{kg}^{-1}\right)$, most of the As was fixed by the mineral matrix (F5, ratios ranging from $46.22 \%$ to $96.37 \%$ ), followed by As bound to Fe and Mn oxides (F3, ratios ranging from $3.14 \%$ to $28.18 \%$ ), and the ratios of the other four fractions (F0, F1, F2 and F4) were mostly less than $10 \%$.

Microbes in the paddy soil can make As transform from inactive fraction (F5) to relatively active fractions (F0, F1, F2 and F3) and thus increase its environmental risk. With the increase of the As addition levels and with the application of manure or chemical NPK fertilizers, As was distributed more in relatively active fractions (F0, F1, F2, F3 and F4) in the paddy soil mediated by the microbes, and the NPK $+\mathrm{M}$ treatment should be paid more attention to for its highest potential environmental risk if the paddy soil was polluted by arsenate. In addition, Fe and Mn oxides of the paddy soil might act as an important role in reducing the As leaching from mineral matrix to soil solution and thus abate the As risk to human health.

\section{Acknowledgements}

This research was financially supported by the National Basic Research Program (Grant No. 2005CB121104) and the Natural Science Foundation of China (40671172, 50621804). We are grateful to X. L. Xie at the Taoyuan Station for his assistance in soil sampling. 


\section{R E F E R E N C E S}

Adriano DC. Trace elements in terrestrial environments, biogeochemistry, bioavailability and the risks of metals. 2nd Ed. New York: Springer; 2001.

Ahmann D, Krumholz LR, Hemond HF, Lovley DR, Morel FMM. Microbial mobilization of arsenic from sediments of the Aberjona Watershed. Environ Sci Technol 1997;31:2923-30.

Anawar HM, Akai J, Yoshioka T, Konohira E, Lee JY, Fukuhara H, et al. Mobilization of arsenic in groundwater of Bangladesh: evidence from an incubation study. Environ Geochem Health 2006;28:553-65.

Bachofen R, Birch L, Buchs U, Ferloni P, Flynn I, Gaudenz J, et al. Volatilization of arsenic compounds by microorganisms. In: Hinche RE, Means JL, Burris DR, editors. Bioremediation of inorganics. Columbus: Battelle Press; 1995. p. 103-8.

Bentley R, Chasteen TG. Microbial methylation of metalloids: arsenic, antimony, and bismuth. Microbiol Mol Biol Rev 2002;66:250-71.

Brouwere KD, Smolders E, Merckx R. Soil properties affecting solid-liquid distribution of $\mathrm{As}(\mathrm{V})$ in soils. Eur J Soil Sci 2004;55:165-73.

Camm GS, Glass HJ, Bryce DW, Butcher AR. Characterisation of a mining-related arsenic-contaminated site, Cornwall, UK. J Geochem Explor 2004;82:1-15.

Cances B, Juillot F, Morin G, Laperche V, Alvarez L, Proux O, et al. XAS evidence of $\mathrm{As}(\mathrm{V})$ association with iron oxyhydroxides in a contaminated soil at a former arsenical pesticide processing plant. Environ Sci Technol 2005;39:9398-405.

Carbonell-Barrachina A, Jugsujinda A, DeLaune RD, Patrick JWH, Burlo F, Sirisukhodom S, et al. The influence of redox chemistry and $\mathrm{pH}$ on chemically active forms of arsenic in sewage sludge-amended soil. Environ Int 1999;25:613-8.

Chang SC, Jackson ML. Fractionation of soil phosphorus. Soil Sci 1957;84:133-44.

Chirenje T, Ma LQ Chen M, Zillioux EJ. Comparison between background concentrations of arsenic in urban and non-urban areas of Florida. Adv Environ Res 2003;8:137-46.

Coker VS, Gault AG, Pearce CI, van der Laan G, Telling ND, Charnock JM, et al. XAS and XMCD evidence for species-dependent partitioning of arsenic during microbial reduction of ferrihydrite to magnetite. Environ Sci Technol 2006; $40: 7745-50$.

Cummings DE, Caccavo F, Fendorf S, Rosenzweig RF. Arsenic mobilization by the dissimilatory Fe(III)-reducing bacterium Shewanella alga BrY. Environ Sci Technol 1999;33:723-9.

deLemos JL, Bostick BC, Renshaw CE, Sturup S, Feng XH. Landfill-stimulated iron reduction and arsenic release at the Coakley Superfund Site (NH). Environ Sci Technol 2006;40:67-73.

Fan XR, Li GW, Shen P. Experiment of microbiology (in Chinese). Beijing: Advanced Education Press; 1992. p. 260-1.

Filgueiras AV, Lavilla I, Bendicho C. Chemical sequential extraction for metal partitioning in environmental solid samples. J Environ Monitor 2002;4:823-57.

Fergusson JE. The heavy elements: chemistry, environmental impact and health effects. Oxford: Pergamon Press; 1990.

Gleyzes C, Tellier S, Astruc M. Fractionation studies of trace elements in contaminated soils and sediments: a review of sequential extraction procedures. Trends Anal Chem 2002;21:451-67.

Gregory RP, Ross FM, Thomas J. Environmental aspects of arsenic toxicity. Crit Rev Clin Lab Sci 1996;33:457-93.

Guo TZ, DeLaune RD, Patrick WH. The influence of sediment redox chemistry on chemically active forms of arsenic, cadmium, chromium, and zinc in estuarine sediment. Environ Int 1997;23:305-16.
Harvey CF, Swartz CH, Badruzzaman ABM, Keon-Blute N, Yu W, Ali $\mathrm{MA}$, et al. Arsenic mobility and groundwater extraction in Bangladesh. Science 2002;298:1602-6.

Islam FS, Gault AG, Boothman C, Polya DA, Charnock JM, Chatterjee $\mathrm{D}$, et al. Role of metal-reducing bacteria in arsenic release from Bengal Delta sediments. Nature 2004;430:68-71.

Jackson BP, Seaman JC, Bertsch PM. Fate of arsenic compounds in poultry litter upon land application. Chemosphere 2006;65:2028-34.

Kairesalo T, Tuominen L, Hartikainen H, Rankinen K. The role of bacteria in the nutrient exchange between sediment and water in a flow-through system. Microb Ecol 1995;29:129-44.

Keon NE, Swartz CH, Brabander DJ, Harvey C, Hemond HF. Validation of an arsenic sequential extraction method for evaluating mobility in sediments. Environ Sci Technol 2001;35:2778-84.

Li YX, Chen TB. Concentrations of additive arsenic in Beijing pig feeds and the residues in pig manure. Resour Conserv Recy 2005;45:356-67.

Lu RK. Analytical Methods of Soil Agricultural Chemistry (in Chinese). Beijing: China Agricultural Science and Technology Press; 2000. p. 12-3, 26-7, 108-9.

Masscheleyn PH, Delaune RD, Patrick WH. Arsenic and selenium chemistry as affected by sediment redox potential and $\mathrm{pH}$. J Environ Qual 1991;20:522-7.

Mukhopadhyay R, Rosen BP, Phung LT, Silver S. Microbial arsenic: from geocycles to genes and enzymes. FEMS Microbiol Rev 2002;26:311-25.

Nolan AL, Lombi E, McLaughlin MJ. Metal bioaccumulation and toxicity in soils - why bother with speciation? Aust J Chem 2003;56:77-91.

Novoa-Munoz JC, Queijeiro JMG, Blanco-Ward D, Alvarez-Olleros C, Garcia-Rodeja E, Martinez-Cortizas A. Arsenic fractionation in agricultural acid soils from NW Spain using a sequential extraction procedure. Sci Total Environ 2007;378:18-22.

O’Neill P. Arsenic. In: Alloway BJ, editor. Heavy Metals in Soils. London: Blackie Academic \& Professional; 1995. p. 105-21.

Okonkwo JO. Arsenic status and distribution in soils at disused cattle dip in South Africa. B Environ Contam Tox 2007;79:380-3.

Oremland RS, Stolz JF. The ecology of arsenic. Science 2003;300:939-44.

Oremland RS, Stolz JF. Arsenic, microbes and contaminated aquifers. Trends Microbiol 2005;13:45-9.

Radloff KA, Cheng ZQ Rahman MW, Ahmed KM, Mailloux BJ, Juhl AR, et al. Mobilization of arsenic during one-year incubations of grey aquifer sands from Araihazar, Bangladesh. Environ Sci Technol 2007;41:3639-45.

Roussel C, Bril H, Fernandez A. Arsenic speciation: involvement in evaluation of environmental impact caused by mine wastes. J Environ Qual 2000;29:182-8.

Rowland HAL, Polya DA, Lloyd JR, Pancost RD. Characterisation of organic matter in a shallow, reducing, arsenic-rich aquifer, West Bengal. Org Geochem 2006;37:1101-14.

Sarkar D, Makris KC, Parra-Noonan MT, Datta R. Effect of soil properties on arsenic fractionation and bioaccessibility in cattle and sheep dipping vat sites. Environ Int 2007;33:164-9.

Shen YF, Sun DJ, Zhao XH, Yu GQ. Screening report in areas of endemic arsenism and high content of arsenic in China. Chin J Endemiol (in Chinese) 2005;24:172-5.

Signes-Pastor A, Burlo F, Mitra K, Carbonell-Barrachina AA. Arsenic biogeochemistry as affected by phosphorus fertilizer addition, redox potential and $\mathrm{pH}$ in a West Bengal (India) soil. Geoderma 2007;137:504-10.

Smith AH, Lingas EO, Rahman M. Contamination of drinking-water by arsenic in Bangladesh: a public health emergency. Bull WHO 2000;78:1093-103.

Tadanier CJ, Schreiber ME, Roller JW. Arsenic mobilization through microbially mediated deflocculation of ferrihydrite. Environ Sci Technol 2005;39:3061-8. 
Tessier A, Campbell PGC, Bisson M. Sequential extraction procedure for the speciation of particulate trace metals. Anal Chem 1979;51:844-51.

Tuominen L, Kairesalo T, Hartikainen H. Comparison of methods for inhibiting bacterial-activity in sediment. Appl Environ Microbiol 1994;60:3454-7.

Turpeinen R, Pantsar-Kallio M, Haggblom M, Kairesalo T. Influence of microbes on the mobilization, toxicity and biomethylation of arsenic in soil. Sci Total Environ 1999;236:173-80.

Van Herreweghe S, Swennen R, Vandecasteele C, Cappuyns V. Solid phase speciation of arsenic by sequential extraction in standard reference materials and industrially contaminated soil samples. Environ Pollut 2003;122:323-42.

Voigt DE, Brantley SL, Hennet RJC. Chemical fixation of arsenic in contaminated soils. Appl Geochem 1996;11:633-43.

Wenzel WW, Kirchbaumer N, Prohaska T, Stingeder G, Lombi E, Adriano DC. Arsenic fractionation in soils using an improved sequential extraction procedure. Anal Chim Acta 2001;436:309-23.

$\mathrm{Xu} \mathrm{HN}, \mathrm{Xu}$ JL. The abnormal region, genesis and distribution of arsenic in China. Soil (in Chinese) 1996:80-4. 